\title{
Analisis Faktor-Faktor Kualitas Pelayanan Terhadap Loyalitas Pasien Di RS. Kusta Dr. Rivai Abdullah Kabupaten Banyuasin Provinsi Sumatera Selatan
}

\author{
Ilhamsyah ${ }^{1}$, Agus Mulyani ${ }^{2}$ \\ ${ }^{1}$ Manajemen, FE Universitas PGRI Palembang, ilhamsyah@univpgri-palembang.ac.id \\ ${ }^{2}$ Manajemen, FE Universitas PGRI Palembang, agusmulyani@univpgri-palembang.ac.id
}

\begin{abstract}
Tujuan dari penelitian ini adalah untuk mengetahui apakah ada faktor-faktor yang mempengaruhi kualitas pelayanan terhadap loyalitas pasien di RS Kusta Dr. Rivai Abdullah Kab. Banyuasin Provinsi Sumatera Selatan. Sebanyak 2.161 pasien per bulan dari populasi 96 pasien, dengan pengambilan sampel adalah metode accidental sampling, Teknik analisis data yang digunakan adalah multiple regresi linker dengan menggunakan SPSS 20.0 for windows. Hasil penelitian menunjukkan variabel bukti langsung Hayward yaitu keandalan, daya tanggap, jaminan, kemudahan secara simultan berpengaruh signifikan terhadap loyalitas untuk mengunjungi pasien di rumah sakit RS. Kusta Dr. Rivai Abdullah Kab. Banyuasin Provinsi Sumatera Selatan dan berdasarkan analisis regresi secara parsial adalah hasil perhitungan yaitu variabel bukti langsung, reliabilitas, daya tanggap, jaminan, kemudahan berpengaruh signifikan. Koefisien regresi dapat dilihat bahwa di antara lima variabel independen yaitu bukti langsung, keandalan, daya tanggap, jaminan dan kemudahan berpengaruh dominan terhadap loyalitas pasien terhadap RS. Kusta Dr. Rivai Abdullah Kab. Banyuasin Provinsi Sumatera Selatan.
\end{abstract}

Kata kunci: Bukti langsung, keandalan, daya tanggap, jaminan, kemudahan, loyalitas pasien

\section{A. PENDAHULUAN}

Untuk mencapai tujuan rumah sakit harus bersaing satu sama lainnya dalam memberikan pelayanan kepada pasein. Rumah sakit yang masuk dalam persaingan ini hendaknya mampu memberikan kualitas jasa atau pelayanan yang baik dengan harapan akan dapat meningkatkan kualitas jasa atau pelayanan yang baik dengan harapan akan dapat meningkatkan kepuasan pasien dan menjadikannya loyal yang menentukan kelangsungan dan keberhasilan rumah sakit untuk tetap eksis

Rumah sakit didirikan bertujuan untuk memberikan pelayanan kesehatan baik dalam bentuk pengobatan, pemeriksaaan kepada pasien yang datang berkunjung. Kegiatan ini memberikan pelayanan kesehatan bagi pasien, jelaskan membutuhkan suatu perangkat pelayanan yang terdiri dari berbagai sarana yang dapat menjalankan fungsinya dari rumah sakit dalam suatu yang terpadu.

Unsur dari suatu kualitas pelayanan yang diberikan menentukan suatu keberhasilan sehingga pasien akan loyal kepada rumah tersebut, adanya layanan yang baik akan memberikan suatu kepuasan tersendiri kepada pasien. Untuk itu perlu adanya pemantauan tata kerja dan tenaga kerja yang profesional. Pelayan yang diberikan dalam waktu yang tepat akan memberikan tingkat kepuasanan bagi pengunjung. Kualitas pelayanan merupakan cara yang dilakukan oleh para petugas RS. Kusta Dr. Rivai Abdullah Kab. Banyuasin Provinsi Sumaterta Selatan untuk pelayanan yang baik merupakan tanggung jawab dari rumah sakit tersebut dalam menciptakan masyarakat yang sehat. Untuk menilai pelayanan dari suatu pusat pelayanan kesehatan tergantung 
pada tingkat loyalitas yang dirasakan oleh pasien yang berkunjung atau berobat.

Puas dan tidak puasnya pelayanan yang dirasakan oleh pengunjung dapat dilihat dari manfaat yang dirasakan oleh pengunjung lebih tinggi jika dibandingkan harapannya. Rumah sakit yang kurang baik biasanya disebebkan oleh faktor-faktor antara lain kurangnya tanggung jawab pimipinan rumah akit, dokter, personil (karyawan) yang kurang terampil, disiplin karyawan yang kurang, sarana dan perasaranan yang kurang lengkap, pembinaan personil yang kurang serta kurangyna kerjasama antara pengunjung dan pihak rumah sakit tersebut.

Berdasarkan inilah maka penulis melakukan penelitian yang berjudul Analisis faktor-faktor kualitas pelayanan terhadap loyalitas pasien di RS. Kusta Dr. Rivai Abdullah Kab. Banyuasin Provinsi Sumaterta Selatan.

Dalam penelitian ini nantinya penulis hanya membatasi penelitian hanya pada pasien rawat jalan umum saja yang datang berobat pada RS. Kusta Dr. Rivai Abdullah yang lebih dari satu kali (loyal) datang berobat. Perumusan masalah adalah faktorfaktor yang paling dominan yang mempengaruhi kualitas pelayanan terhadap loyalitas pasein di RS. Kusta Dr. Rivai Abdullah Kab. Banyuasin Provinsi Sumaterta Selatan.

\section{B. LANDASAN TEORI}

\section{Teori Kualitas Pelayanan}

Menurut Kotler (2009:464) menyatakan bahwa Pelayanan adalah tindakan atau perbutan yang ditawarkan oleh suatu pihak yang pada dasarnya bersifat tidak berwujud fisik dan tidak menghasilkan kepemilikan sesuatu.

Pelayanan diwujudkan melalui pemenuhan kebutuhan yang diinginkan oleh pelanggan serta ketepatan penyampaian dalam memenuhi atau melampaui harapan pelanggan Tjiptono (2008:70)

Menurut Weich (Kotler 2009:56) menyatakan bahwa pelayanan merupakan jaminan terbaik atas kesetiaan pelanggan, pertahanan terkuat dalam menghadapi persaingan asing dan satu-satunya jalan untuk menuju pertumbuhan dan pendapatan yang langgeng.

Kualitas pelayanan yang baik adalah dapat menjadi salah satu faktor yang dapat meningkatkan minat pelanggan terhadap produk dan jasa, oleh karena faktor kualitas pelayanan harus mendapat perhatian dan perioritas utama dalam meningkatkan kualitas pelayanan khususnya dibidang pelayanan jasa kesehatan.

Dari berbagai definisis dapat disimpulkan pengertian dari Kualitas pelayanan yaitu segala bentuk penyelenggara pelayan secara maksimal kebutuhan pelanggan demi memenuhi harapan pelanggan khususnya pasien.

Menurut Tjiptono (2008:146) menyatakan bahwa faktor-faktor yang biasanya dijadikan indikator dalam mengevaluasi jasa layanan antara lain:

a. Tangibility, bukti langsung meliputi fasilitas fisik, perlengkapan, pegawai dan sarana komunikasi

b. Realibility, keandalan yaitu kemampuan memberikan pelayanan yang dijanjikan dengan segera, akurat yang memuaskan

c. Responsiveness, daya tanggap yaitu keinginan para staf dan karyawan untuk membantu para pelanggan dan memberikan pelayanan yang tanggap

d. Assurance, jaminan mencakup pengetahuan, kemampuan, kesopanan dan sifat dapat 
dipercaya yang dimiliki oleh staf, bebas dari bahaya, resiko atau keraguan.

e. Empaty, meliputi kemudahan dalam melakukan hubungan, komunikasi yang baik, perhatian pribadi.

Kualitas pelayanan kepada
konsumen atau pelanggan
berpengaruh terhadap kepuasan
pelanggan, dimana pelayanan yang
buruk berakibat lebih besar terhadap
kepuasan pelanggan dari pada
pelayanan yang dikategorikan terbaik.
Implementasi strategi yas
dikategorikan terburuk akan
menurunkan kepuasan dan kesetian
atau loyalitas konsumen dalam
Lupiyoadi (2006:140)
Jadi pelayanan yang diberikan
kepada pelanggan (pasien) sesuai
dengan yang diharapkan maka akan
memberikan kepuasan, oleh karena itu
kualitas pelayanan harus terus
ditingkatkan sehingga mencapai apa
yang diharapkan oleh pelanggan
khususnya pasein.

\section{Teori Loyalitas}

Loyalitas adalah komitmen atau pelanggan bertahan secara mendalam untuk melakukan pembelian ulang produk atau jasa menurut pendapat Oliver dalam Ratih (2010:128) sedangkan menurut Evans dan Laskin, konsumen yang loyal adalah konsumen yang bersedia melakukan pembelian ulang (Repeat purchase) baik produk atau jasa dari produsen yang sama dan kebal terhadap bujukan dari pesaing.

Menurut Kurz dan Clow dalam Laksana (2008:97) bahwa jika pelayanan yang diberikan kepada pelanggan sesuai dengan yang diharapkan maka akan memberikan kepuasan sehingga pelanggan akan loyal akan produk atau jasa. Dengan demikian jika kualitas pelayanan terus ditingkatkan sehingga mencapai apa yang diharapkan oleh pelanggan maka pelanggan akan puas sehingga akan loyal dengan produk atau jasa.

Menurut Griffin dalam Ratih (2010:130) menyatakan bahwa konsumen yang loyal merupakan asset tak ternilai bagi perusahaan, hal ini dapat dilihat dari karateristik yang dimilikinya. Sehingga keuntungan yang akan diperoleh apabila memiliki pelanggan yang loyal antara lain:
1. Dapat mengurangi biaya pemasaran
2. Dapat mengurangi biaya transaksi
3. Dapat mengurangi biaya turn over konsumsi

4. Dapat meningkatkan penjualan silang, yang akan memperbesar pangsa pasar perusahaan

5. Mendorong word of mouth yang lebih positif, dengan asumsi bahwa pelanggan yang loyal juga berarti mereka yang merasa puas
6. Dapat mengurangi biaya kegagalan

Terdapat 14 hal yang perlu diperhatikan oleh perusahaan agar first time buyers melakukan pembelian ulang menurut Griffin (2002:21) adalah sebagai berikut:

1. Tidak lupa mengucapkan terima kasih setelah transaksi terjadi

2. Meminta umpan balik dari mereka dan memberikan respon dengan segera

3. Gunakan surat yang tidak mendoktrin, maksudnya surat yang berisi tentang cara-cara menggunakan produk atau jasa tanpa bermaksud menggurui

4. Tingkatkan nilai perusahaan secara terus menerus

5. Menyusun database konsumen

6. Komunikasi secara terus menerus 
7. Memberi gambaran tentang kepemilikan

8. Mengubah pembelian ulang menjadi pelayanan

9. Memperlakukan biaya pelayanan untuk pelanggan sebagai investasi bernilai

10. Menjamin komunikasi dengan pengambilan keputusan

11. Mengembangkan komunikasi dengan mengambil keputusan

12. Mengembangkan promosi untuk pelanggan baru

13. Menawarkan garansi produk

14. Mengembangkan promosi nilai tambah produk

Menurut Griffin
menyatakan $\begin{gathered}(2002: 300) \\ \text { bahwa }\end{gathered}$
konsumen yang memiliki karateristik
yang dapat dijadikan indikator untuk
mengukur loyalitas pelanggan (pasien)
yaitu:

a. Melakukan pembelian secara teratur (Maker regular repet purchase)

b. Membeli diluar lini produk/jasa (Purchases across product and servis lines)

c. Merekomendasikan produk lain (Refers orher)

d. Menunjukan kekebalan dari daya tarik produk sejenis dari pesaing

(Demonstrates on immunity to the full of the competition)

\section{METODE PENELITIAN}

Penelitian ini menggunakan metode survey kuantitatif dengan pendekatan deskriptif. Menurut Siswoyo, survey adalah suatu teknik penelitian dimana informasi dikumpulkan melalui penggunaan angket atau kuesioner.

Rancangan penelitian ini terdiri atas variabel bebas Kualitas Pelayanan $(X)$ dan Variabel terikat yaitu Loyalitas pasien $(\mathrm{Y})$

\section{POPULASI DAN SAMPEL}

Menurut Sugiyono (2010:55) menyatakan bahwa populasi adalah wilayah generalisasi yang terdiri atas objek atau subjek yang mempunyai kuantitas dan karakteristik tertentu yang diterapkan oleh peneliti untuk dipelajari dan kemudian ditarik kesimpulannya. Data kunjungan pasien berdasarkan jumlah rawat jalan umum RS. Kusta Dr. Rivai Abdullah yang berjumlah 25.928 dari laporan hasil kerja kegiatan bulan Januari sampai bulan Desember Tahun 2013 (data www:http://www.rskusta-

palembang.com).

Tabel 1

Data Kunjungan Pasien Rawat Jalan Umum

\begin{tabular}{|c|c|c|}
\hline No & Bulan & Jumlah Pasien \\
\hline 1 & Januari & 2.499 \\
2 & Februari & 2.439 \\
3 & Maret & 2.831 \\
4 & April & 2.175 \\
5 & Mei & 2.474 \\
6 & Juni & 2.237 \\
7 & Juli & 2.146 \\
8 & Agustus & 1.715 \\
9 & September & 2.030 \\
10 & Oktober & 2.105 \\
11 & November & 2.243 \\
12 & Desember & 2.260 \\
\hline & $\mathbf{J ~ u ~} \mathbf{~} \mathbf{~ I ~ a ~ h ~}$ & $\mathbf{2 5 . 9 2 8}$ \\
\hline
\end{tabular}


Adapun populasi dalam penelitian ini dihitung melalui rata-rata jumlah pasien setiap bulannya ini adalah:

Populasi $(\mathrm{N})=25.928$

$=2 \cdot \frac{160,67}{12}=2.161$ pasien

Sedangkan menurut Sugiyono (2010:65) bahwa Sampel adalah sebagian atau wakil populasi yang diteliti menggunakan Metode Accidental Sample yaitu sampel yang diambil dengan cara kebetulan. Dengan demikian sampel yang diambil adalah pasien yang kebetulan menggunakan pelayanan di RS. Kusta Dr. Rivai Abdullah Kab. Banyuasin Provinsi Sumaterta Selatan. Adapun rumus yang digunakan dalam pengambilan sampel adalah Rumus Slovin sebagai berikut:

Sampel $(n)=N /\left(1+\left(N \cdot e^{2}\right)\right.$

Dimana:

$\mathrm{n}=$ Jumlah sampel

$\mathrm{N}=$ Jumlah populasi

$\mathrm{e}=$ tingkat kesalahan karena kesalahan dalam pengambilan sampel yang masih dapat ditolerir atau diizinkan, diambil sebesar $10 \%$, maka besarnya sampel adalah:

Sampel $(n)=2 \cdot 161 /\left(1+\left(1 \cdot 161 \cdot 0,1^{2}\right)\right.$ $=95,57=96$ pasien

\section{E. TEKNIK PENGUMPULAN DATA}

Teknik mengumpulkan data berkaitan dengan kegiatan penelitian ini akan digunakan alat-alat pengumpulan data yaitu angket dan dokumentasi.

\section{F. TEKNIK ANALISIS DATA}

1. Analisis Regresi Linier Berganda Analisis statistik yang digunakan dalam penelitian ini adalah menggunakan analisis regresi berganda dengan program SPSS 21 (Santoso, 2013:347) yang berguna untuk menghitung besarnya pengaruh secara kuantitatif dari suatu perubahan kejadian kejadian (Variabel $X$ ) terhadap kejadian lainnya (Variabel $Y$ ). Dalam penelitian, analisis regresi berganda berperan sebagai teknik statistik yang digunakan untuk menguji ada tidaknya pengaruh faktor-faktor Tangibility (Bukti langsung), Realibility (Keandalan), Responsiveness (Daya tanggap), Assurance (Jaminan) dan Empaty (Kemudahan) terhadap loyalitas pasien di RS. Kusta Dr. Rivai Abdullah Provinsi Sumatera Selatan

Analisis regresi menggunakan rumus persamaan regresi berganda (Santoso, 2013:347) yaitu:

$\mathrm{Y}=\mathrm{b}_{0}+\mathrm{b}_{1} \mathrm{X}_{1}+\mathrm{b}_{2} \mathrm{X}_{2}+\mathrm{b}_{3} \mathrm{X}_{3}+\mathrm{b}_{4} \mathrm{X}_{4}+$ $\mathrm{b}_{5} \mathrm{X}_{5}+\mathrm{e}$

Dimana :

$\mathrm{Y}=$ Kualitas pelayanan

$\mathrm{b}_{0}=$ Nilai konstanta

$\mathrm{b}=$ Koefisien regresi

$\mathrm{e}=$ Kesalahan observasi atau pengganggu (merupakan bentuk variabel lainnya yang tidak diteliti oleh peneliti)

$\mathrm{X}_{1}=$ Bukti langsung $\mathrm{X}_{2}=$ Keandalan

$\mathrm{X}_{3}=$ Daya tanggap $\mathrm{X}_{4}=$ Jaminan

$\mathrm{X}_{5}=$ Kemudahan

2. Analisis Koefisien Determinasi $\left(R^{2}\right)$ Untuk melihat kemampuan variabel bebas dalam menerangkan variabel tidak bebasnya dapat diketahui dengan melihat koefisien diterminasi berganda $\mathrm{R}$ (Santoso, 2013:362). Bila R mendekati angka 1, maka sumbangan variabel bebas terhadap variabel tergantung semakin besar. Bila R mendekati angka 0 (nol), berarti sumbangan dari variabel bebas terhadap variabel terikat semakin lemah.

\section{G. TEKNIK PENGUJIAN INSTRUMEN}

Tahapan-tahapan yang penulis gunakan dalam menganalisis penelitian ini adalah sbb: 
1. Uji Validitas Instrumen

Uji validitas adalah suatu ukuran yang menunjukkan tingkat-tingkat kevalidan sesuatu instrumen (Arikunto,2006:168). Suatu instrumen yang valid atau sahih mempunyai validitas tinggi. Sebaliknya instrumen yang kurang valid berarti memiliki validitas rendah.

Sebuah instrumen dikatakan valid apabila mampu mengukur apa yang diinginkan. Sebuah instrumen dikatakan valid apabila dapat mengungkap data dari variabel yang diteliti secara tepat. Tinggi rendahnya instumen menunjukkan sejauh mana data yang terkumpul tidak menyimpang dari gambaran tentang variabel yang dimaksud.

Alat untuk mengukur validitas adalah Korelasi Product Moment Pearson (Arikunto,2006:170). Suatu indikator dikatakan valid, apabila $\mathrm{n}=96$ dan $\alpha=0,05$ maka $r_{\text {tabel }}=0,195$ dengan ketentuan (Arikunto, 2006:184):

Hasil $r_{\text {hit }}>r_{\text {tabel }}(0,195)=$ valid Hasil $r_{\text {hit }}<r_{\text {tabel }}(0,195)=$ tidak valid.

2. Uji Reliabilitas Instrumen

Uji reliabilitas adalah sesuatu instrumen cukup dapat dipercaya untuk digunakan sebagai alat pengumpul data karena instrumen tersebut sudah baik (Arikunto,2006:178). Instrumen yang baik tidak akan bersifat tendensius atau mengarahkan responden untuk memilih jawaban-jawaban tertentu. Instrumen yang sudah dapat dipercaya, yang reliabel akan menghasilkan data yang dapat dipercaya, apabila datanya benar-benar sesuai dengan kenyataannya, maka berapa kalipun diambil, tetap akan sama. Reliabilitas menunjukkan pada tingkat keandalan (dapat dipercaya).

Di sini yang dapat dipercaya adalah datanya, bukan sematamata instrumennya (Arikunto,2006:179). Instrumen yang reliabel mengandung arti bahwa instrumen tersebut harus baik sehingga mampu mengungkap data yang bisa dipercaya.

Alat untuk mengukur reliabilitas adalah Alpha Cronbach (Arikunto,2006:196). Suatu variabel dikatakan reliabel, apabila (Nurgiyantoro,2004: 352): Hasil a $\square 0,60=$ reliabel Hasil $\alpha<0,60=$ tidak reliabel.

Dikemukakan(Sugiyono 2010:69) bahwa statistik parametriks bekerja dengan asumsi data setiap variabel memenuhi normal, homogen dan linier. Bila data tidak normal, homogeny dan linier, maka statistic parametric tidak dapat digunakan untuk alat analisis, yaitu :

\section{Uji Asumsi}

a. Uji Normalitas Data

Uji normalitas bertujuan untuk menguji apakah data yang akan digunakan dalam model regresi berdistribusi normal atau tidak (Ghozali,2005:110).

Untuk menguji suatu data berdistribusi normal atau tidak, dapat diketahui dengan menggunakan grafik normal plot (Ghozali,2005:112). Pada grafik normal plot, dengan asumsi :

1) Apabila data menyebar disekitar garis diagonal dan mengikuti arah garis diagonal atau grafik histogramnya menunjukkan pola distribusi normal, maka model regresi memenuhi 
asumsi normalitas.

2) Apabila data menyebar jauh dari diagonal dan atau tidak mengikuti arah garis diagonal atau grafik histogram tidak menunjukkan pola distribusi normal, maka model regresi tidak memenuhi uji asumsi normalitas.

b. Uji Heteroskedastisitas

Uji heteroskedastisitas bertujuan menguji apakah dalam model regresi terjadi ketidaksamaan variansi dari residual satu pengamatan

kepengamatan yang lain. Jika variansi dari residual satu pengamatan ke pengamatan lain tetap, maka disebut homokedastisitas dan jika berbeda disebut heteroskedastisitas. Model regresi yang baik adalah omokedastisitas atau tidak terjadi heteroskedastisitas (Ghozali,2005:105). Deteksi ada tidaknya problem heteroskedastisitas adalah dengan media grafik, apabila grafik membentuk pola khusus maka model terdapat heteroskedastisitas (Ghozali, 2005:105).

Dasar keputusan:

1) Jika ada pola tertentu, seperti titik-titik (point- point) yang ada membentuk suatu pola tertentu yang teratur (bergelombang, melebar kemudian menyempit), maka telah terjadi heteroskedaastisitas.

2) Jika tidak ada pola yang jelas, serta titik-titik menyebar di atas dan dibawah angka 0 pada sumbu $\mathrm{Y}$, maka tidak terjadi heteroskedaastisitas. c. Uji Multikolinearitas

Uji multikolinearitas bertujuan untuk menguji apakah model regresi ditemukan adanya korelasi antar variabel bebas. Model regresi yang baik seharusnya tidak terjadi korelasi di antara variabel bebas. Jika variabel bebas saling berkorelasi, maka variabel-variabel ini tidak ortogonal. Variabel ortogonal adalah variabel bebas yang nilai korelasi antar sesama variabel bebas sama dengan nol (0). Untuk mendeteksi ada atau tidaknya multikolinearitas di dalam model regresi (Ghozali,2005:92) adalah sebagai berikut:

1) Mempunyai angka Tolerance diatas $(>)$ 0,1

2) Mempunyai nilai VIF di di bawah (<) 10

\section{Uji Hipotetis}

Untuk membuktikan hipotesis dalam penelitian ini apakah variabel bebas berpengaruh terhadap variabel terikat, maka digunakan beberapa pengujian yaitu:

a. Uji-t (Uji Parsial)

Untuk menguji apakah masingmasing variable bebas berpengaruh secara signifikan terhadap variabel terikat secara parsial (Sugiyono,2012:73) dengan $\square=0,05$ dan juga penerimaan atau penolakan hipotesa, maka cara yang dilakukan adalah:

1) Merumuskan hipotesis
a) $\mathrm{H}_{01}$ : Tidak ada pengaruh yang signifikan antara bukti fisik terhadap loyalitas pasien secara parsial
b) $\mathrm{H}_{\mathrm{a} 1}$ : Ada ada pengaruh yang signifikan antara bukti fisik terhadap loyalitas pasien secara parsial
c) $\mathrm{H}_{02}$ : Tidak ada pengaruh 
yang signifikan antara keandalan terhadap loyalitas pasien secara parsial

d) $\mathrm{H}_{\mathrm{a} 2}$ : Ada ada pengaruh yang signifikan antara keandalan terhadap loyalitas pasien secara parsial

e) $\mathrm{H}_{03}$ : Tidak ada pengaruh yang signifikan antara daya tanggap terhadap loyalitas pasien secara parsial

f) $\mathrm{H}_{\mathrm{a} 3}$ : Ada ada pengaruh yang signifikan antara daya tanggap terhadap loyalitas pasien secara parsial

g) $\mathrm{H}_{04}$ : Tidak ada pengaruh yang signifikan antara jaminan terhadap loyalitas pasien secara parsial

h) $\mathrm{H}_{\mathrm{a} 4}$ : Ada ada pengaruh yang signifikan antara jaminan terhadap loyalitas pasien secara parsial

i) $\mathrm{H}_{05}$ : Tidak ada pengaruh yang signifikan antara empati terhadap loyalitas pasien secara parsial

j) $\mathrm{H}_{\mathrm{a} 5}$ : Ada ada pengaruh yang signifikan antara empati terhadap loyalitas pasien secara parsial

2) Mencari thitung Rumus:

$$
\text { thit }=\underline{R} \sqrt{n-2}
$$

$$
\boldsymbol{f}^{1-\mathrm{R}^{2}}
$$

variabel bebas

$\mathrm{k}$ = Banyaknya Korelasi

Keterangan:

$\mathrm{R}=$ Koefisien sampel

$\mathrm{n}$ = Banyaknya

$\mathrm{R}^{2}=$ Koefisien

Dengan asumsi $(F)$ :

Determinasi sampel:

$\mathrm{n}$ = Banyaknya dengan asumsi (thitung)

sig. $>\square=0,05$

$$
\square \square=0,05 \text { hitung }
$$

Ho : diterima bila Ho : ditolak bila sig.

Ho : diterima bila sig. $>\square=0,05$

Ho : ditolak bila sig. $\square \square=0,05$

\section{b. Uji-F (Uji Serempak)}

Untuk menguji apakah masingmasing variable bebas berpengaruh secara signifikan terhadap variabel terikat (Sugiyono,2012:75) secara bersama-sama dengan $\square=0,05$ dan juga penerimaan atau penolakan hipotesa, maka cara yang dilakukan adalah:

1) Merumuskan hipotesis

a) $\mathrm{H}_{06}$ : Tidak ada pengaruh yang signifikan antarabukti fisik, keandalan, daya tanggap, jaminan dan empati terhadap loyalitas pasien secara simultan

b) $\mathrm{H}_{\mathrm{a} 6}$ : Ada ada pengaruh yang signifikan antara bukti fisik, keandalan, daya tanggap, jaminan dan empati terhadap loyalitas pasien secara simultan

2) Mencari $F_{\text {hitung }}$ Rumus:

$$
\begin{aligned}
& F_{\text {hit }}=R 2 / k-1 \\
& (1-R 2) /(n-k)
\end{aligned}
$$

\section{Analisis Koefisien Determinasi} (RSquare)

Koefisien determinasi $\left(R^{2}\right)$ pada intinya mengukur seberapa jauh kemampuan model (bukti fisik, keandalan, daya tanggap, jaminan dan empati) dalam menerangkan variasi variabel dependen atau tidak bebas (loyalitas pasien). Nilai koefisien determinasi adalah antara nol (0) dan satu (1). Nilai $R^{2}$ yang kecil berarti kemampuan variable - variabel independen (bebas) dalam menjelaskan variasi variabel dependen amat terbatas. Nilai yang mendekati satu berarti variable - variabel independen memberikan hampir semua informasi yang dibutuhkan 
untuk memprediksi variasi variabel dependen. Secara umum koefisien determinasi untuk data silang (crosssection) relatif rendah karena adanya variasi yang besar antara masing-masing pengamatan, sedangkan untuk data runtun waktu (time series) biasanya mempunyai nilai koefisien determinasi yang tinggi (Ghozali,2005:83).

Banyak peneliti menganjurkan untuk menggunakan nilai Adjusted $R^{2}$ (Adjusted $R$ Square) pada saat mengevaluasi mana model regresi terbaik. Tidak seperti $\mathrm{R}^{2}$, nilai Adjusted $\mathrm{R}^{2}$ dapat naik atau turun apabila satu variabel independen ditambahkan ke dalam model (Ghozali,2005:83).

Dalam kenyataan nilai Adjusted $R^{2}$ dapat bernilai negatif, walaupun yang dikehendaki harus bernilai positif.
Jika dalam uji empiris didapat nilai Adjusted $\mathrm{R}^{2}$ negatif, maka nilai Adjusted dianggap bernilai 0 . Secara matematis jika nilai $R^{2}=1$, maka Adjusted $\mathrm{R}^{2}=\mathrm{R}^{2}=1$.

Sedangkan jika nilai $R^{2}=0$, maka Adjusted $\mathrm{R}^{2}=(1-\mathrm{k}) /(\mathrm{n}-\mathrm{k})$. Jika $\mathrm{k}>1$, maka Adjusted $\mathrm{R}^{2}$ akan bernilai negatif.

$$
\begin{aligned}
& \text { Fhit }=R^{2} / k-1 \\
&\left(1-R^{2}\right) /(n-k)
\end{aligned}
$$

Dalam penelitian ini, untuk mengolah data digunakan alat bantu SPSS (Statistical Package for Social Science)

\section{Determinasi}

Keterangan:

$\mathrm{R}^{2}=$ Koefisien

\section{H. HASIL PENELITIAN}

\section{Analisis Data}

Tabel 2

\begin{tabular}{|c|c|c|c|c|}
\hline Variabel & Butir & $\mathbf{R}_{\text {hitung }}$ & Cronbach's alpha & Keterangan \\
\hline Bukti langsung (X1) & $\begin{array}{l}1 \\
2 \\
3 \\
4 \\
5\end{array}$ & $\begin{array}{l}\left..590^{* \star}{ }^{*}\right) \\
\left..765^{\star *}\right) \\
\left..502^{* *}\right) \\
\left..675^{* \star}\right) \\
\left..570^{* \star}\right)\end{array}$ & 0.60 & $\begin{array}{l}\text { Valid dan Reliabel } \\
\text { Valid dan Reliabel } \\
\text { Valid dan Reliabel } \\
\text { Valid dan Reliabel } \\
\text { Valid dan Reliabel }\end{array}$ \\
\hline Kehandalan (X2) & $\begin{array}{r}6 \\
7 \\
8 \\
9 \\
10\end{array}$ & $\begin{array}{l}\left..5833^{\star \star}\right) \\
\left..581^{\star \star *}\right) \\
\left..824^{\star *}\right) \\
\left..7522^{\star *}\right) \\
\left..580^{\star \star}\right)\end{array}$ & 0.68 & $\begin{array}{l}\text { Valid dan Reliabel } \\
\text { Valid dan Reliabel } \\
\text { Valid dan Reliabel } \\
\text { Valid dan Reliabel } \\
\text { Valid dan Reliabel }\end{array}$ \\
\hline Daya tanggap (X3) & $\begin{array}{l}11 \\
12 \\
13 \\
14 \\
15\end{array}$ & $\begin{array}{l}\left..7755^{\star \star}\right) \\
.89\left(^{* \star}\right) \\
\left..8755^{\star *}\right) \\
\left..816^{\star *}\right) \\
\left..772^{* *}\right)\end{array}$ & 0.88 & $\begin{array}{l}\text { Valid dan Reliabel } \\
\text { Valid dan Reliabel } \\
\text { Valid dan Reliabel } \\
\text { Valid dan Reliabel } \\
\text { Valid dan Reliabel }\end{array}$ \\
\hline Jaminan (X4) & $\begin{array}{l}16 \\
17 \\
18 \\
19 \\
20\end{array}$ & $\begin{array}{l}.684\left(^{* \star}\right) \\
.69\left(^{* \star}\right) \\
\left..7799^{\star *}\right) \\
\left..509^{* *}\right) \\
.680\left(^{* *}\right)\end{array}$ & 0.70 & $\begin{array}{l}\text { Valid dan Reliabel } \\
\text { Valid dan Reliabel } \\
\text { Valid dan Reliabel } \\
\text { Valid dan Reliabel } \\
\text { Valid dan Reliabel }\end{array}$ \\
\hline
\end{tabular}

Uji Validitas dan Reliabilitas 


\begin{tabular}{|c|c|c|c|c|}
\hline Kemudahan (X5) & 21 & $.583\left(^{* *}\right.$ & & Valid dan Reliabel \\
& 22 & $.581\left(^{* *}\right)$ & & Valid dan Reliabel \\
& 23 & $.824\left(^{* *}\right)$ & 0.68 & Valid dan Reliabel \\
& 24 & $.752\left(^{* *}\right)$ & & Valid dan Reliabel \\
& 25 & $\left..580{ }^{* *}\right)$ & & Valid dan Reliabel \\
\hline Loyalitas pasien (Y) & 26 & $.810\left(^{* *}\right)$ & & Valid dan Reliabel \\
& 27 & $.919\left(^{* *}\right)$ & & Valid dan Reliabel \\
& 28 & $.905\left(^{* *}\right)$ & 0.92 & Valid dan Reliabel \\
& 29 & $.864\left(^{* *}\right)$ & & Valid dan Reliabel \\
& 30 & $.862\left(^{* *}\right)$ & & Valid dan Reliabel \\
\hline
\end{tabular}

\section{Uji Asumsi Klasik}

\section{Uji Normalitas}

Dalam sebaran (pencaran) data berada di sekitar garis diagonal dan tidak ada yang terpencar jauh dari garis diagonal, sehingga asumsi normalitas dapat dipenuhi.

2. Uji Heteroskedastisitas

Terlihat pada gambar 2 diatas bahwa titik ada pada pola tertentu seperti titik-titik (point-point) yang membentuk suatu pola tertentu teratur, bergelombang, melebar, kemudian menyempit, serta titiktitik menyebar di atas dan di bawah angka 0 pada sumbu $Y$ maka model regresi yang diperoleh tidak terjadi masalah heteroskedastisitas

\section{Pengujian Multikolinearitas}

Tabel 3

Hasil Uji Multikolinearitas

\begin{tabular}{|c|c|c|}
\hline \multirow{2}{*}{ Model } & Collinearity & Statistics \\
\cline { 2 - 3 } & Tolerance & VIF \\
\hline Bukti langsung (X1) & 0.554 & 1.805 \\
Kehandalan (X2 & 0.778 & 1.286 \\
Daya tanggap (X3) & 0.511 & 1.957 \\
Jaminan (X4) & 0.778 & 1.286 \\
Kemudahan (X5) & 0.713 & 1.402 \\
\hline
\end{tabular}

\section{Analisis Regresi Berganda}

\section{Tabel 4}

Rekapitulasi Hasil Regresi Berganda

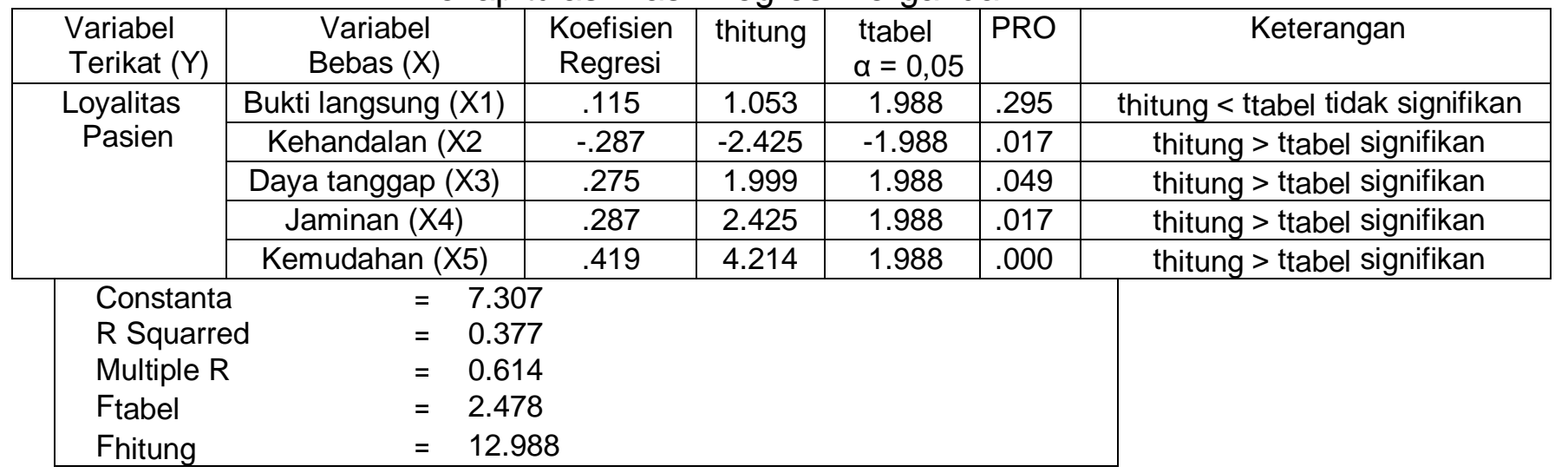


$Y=7,307+0,115 X_{1}-0,287 X_{2}+$

$0,275 X_{3}+0,287 X_{4}+0,419 X_{5}$

Berarti model regresi pada tabel 5.25 diatas maka dapat diuraikan sebagai berikut:

1. Untuk setiap kontribusi dari variabel bukti langsung $\left(\mathrm{X}_{1}\right)$ akan mempengaruhi loyalitas pasien (Y) sebesar 0,115 dengan asumsi bahwa variabel kehandalan $\left(\mathrm{X}_{2}\right)$, Daya tanggap $\left(X_{3}\right)$, jaminan $\left(X_{4}\right)$, kemudahan $\left(X_{5}\right)$ konstan. Dan setiap penambahan 1 poin bukti langsung maka akan meningkatkan loyalitas pasien di RS. Kusta Dr. Rivai Abdullah Provinsi Sumatera Selatan sebesar 0,115

2. Untuk setiap kontribusi dari variabel kehandalan $\left(\mathrm{X}_{2}\right)$ akan mempengaruhi loyalitas pasien (Y) sebesar $-0,287$ dengan asumsi bahwa variabel bukti langsung $\left(X_{1}\right)$, daya tanggap $\left(X_{3}\right)$, jaminan $\left(X_{4}\right)$, kemudahan $\left(X_{5}\right)$ konstan. Dan setiap penambahan 1 poin kehandalan maka akan meningkatkan loyalitas pasien di RS. Kusta Dr. Rivai Abdullah Provinsi Sumatera Selatan sebesar 0,287

3. Untuk setiap kontribusi dari variabel daya tanggap $\left(\mathrm{X}_{3}\right)$ akan mempengaruhi loyalitas pasien (Y) sebesar 0,275 dengan asumsi bahwa variabel bukti langsung $\left(X_{1}\right)$, kehandalan $\left(X_{2}\right)$, jaminan $\left(X_{4}\right)$, kemudahan $\left(X_{5}\right)$ konstan. Dan setiap penambahan 1 poin daya tanggap maka akan meningkatkan loyalitas pasien di RS. Kusta Dr. Rivai Abdullah Provinsi Sumatera Selatan sebesar 0,275

4. Untuk setiap kontribusi dari variabel jaminan $\left(X_{4}\right)$ akan mempengaruhi loyalitas pasien (Y) sebesar 0,287 dengan asumsi bahwa variabel bukti langsung $\left(X_{1}\right)$, kehandalan $\left(X_{2}\right)$, daya tanggap $\left(X_{3}\right)$, kemudahan $\left(X_{5}\right)$ konstan. Dan setiap penambahan 1 poin jaminan maka akan meningkatkan loyalitas pasien di RS. Kusta Dr. Rivai Abdullah Provinsi Sumatera Selatan sebesar 0,287

5. Untuk setiap kontribusi dari variabel kemudahan $\left(X_{5}\right)$ akan mempengaruhi loyalitas pasien (Y) sebesar 0,419 dengan asumsi bahwa variabel bukti langsung $\left(X_{1}\right)$, kehandalan $\left(X_{2}\right)$, daya tanggap $\left(X_{3}\right)$, jaminan $\left(X_{4}\right)$ konstan. Dan setiap penambahan 1 poin kemudahan maka akan meningkatkan loyalitas pasien di RS. Kusta Dr. Rivai Abdullah Provinsi Sumatera Selatan sebesar 0,419.

Maka dapat disimpulkan bahwa variabel bukti langsung, daya tanggap, jaminan dan kemudahan memiliki pengaruh yang positif terhadap loyalitas pasien di RS. Kusta Dr. Rivai Abdullah Provinsi Sumatera Selatan, sedangkan variabel kehandalan mempunyai pengaruh yang negatif. Variabel yang paling dominan mempengaruhi loyalitas pasien tersebut adalah variabel kemudahan dengan nilai koefisien regresi yang paling besar yaitu 0,419 atau dengan nilai thitung sebesar 4,214

\section{Pengujian Hipotesis}

1. Uji-F (Simultan)

Analisis hasil pengujian hipotesis menunjukkan bahwa variabel-variabel perilaku konsumen secara bersamasama berpengaruh signifikan terhadap loyalitas pasien. Ini bisa di lihat dari nilai $F_{\text {hitung }}(12,988)<F_{\text {tabel }}(2,478)$. Hubungan antara variabel-variabel 
bebas terhadap variabel terikat menunjukkan hubungan yang erat sebesar $61,4 \%$.

\section{Uji - t (Parsial)}

Berdasarkan tabel hasil regresi berganda dapat ditarik kesimpulan bahwa komponen perilaku konsumen yang dominan mempengaruhi loyalitas pasien yaitu variabel kemudahan $\left(X_{5}\right)$ dengan kontribusi sebesar 0,419. Hal ini menunjukkan bahwa faktor yang paling dominan mempengaruhi loyalitas pasien untuk berkunjung dan berobat di RS. Kusta Dr. Rivai Abdullah Provinsi Sumatera Selatan tidak terbukti.

\section{Koefisien Determinasi}

Koefisien determinasi digunakan untuk mengetahui kemampuan variabel independen dalam menjelaskan variabel dependen. Besarnya koefesien determinasi dapat dilihat pada adjsuted $r$ square dan dinyatakan dalam pesentase.

Hasil Koefisien determinan berganda sebesar 0,377 menunjukkan bahwa loyalitas pasien RS. Kusta Dr. Rivai Abdullah Provinsi Sumatera Selatan dijelaskan oleh bukti langsung, kehandalan, daya tanggap, jaminan dan kemudahan sebesar $37,7 \%$ sedangkan sisanya $62,3 \%$ ditentukan oleh variabel diluar model.

\section{PEMBAHASAN}

1. Bukti Langsung terhadap Loyalitas Pasien Menurut hasil perhitungan statistic ternyata bahwa faktor bukti langsung mempunyai hubungan positif satu arah, hal ini berarti bila bukti langsung ditingkatkan maka loyalitas pasien untuk berkunjung dan berobat pada RS. Kusta Dr. Rivai Abdullah Provinsi Sumatera Selatan juga meningkat pula. Hal ini terbukti dengan nilai thitung untuk variabel ini sebesar 1,053.
Sementara itu nilai pada tabel distribusi $5 \%$ sebesar 1,988, maka thitung $(1,503)<t_{\text {tabel }}$ $(1,988)$. Hal ini berarti variabel bukti langsung tidak mempunyai pengaruh yang signifikan. Hal ini juga diperkuat dengan nilai signifikan $0,05 \quad(0,295>0,05)$ artinya variabel bukti fisik tidak berpengaruh signifikan terhadap loyalitas pasien untuk berkunjung dan berobat pada RS. Kusta Dr. Rivai Abdullah Provinsi Sumatera Selatan.

2. Kehandalan Terhadap Loyalitas Pasien Menurut hasil perhitungan statistic ternyata bahwa faktor kehandalan mempunyai hubungan negatif, hal ini berarti bila faktor kehandalan menurun maka loyalitas pasien untuk berkunjung dan berobat pada RS. Kusta Dr. Rivai Abdullah Provinsi Sumatera Selatan juga menurun pula. Hal ini terbukti dengan nilai thitung untuk variabel ini sebesar 2,425 . Sementara itu nilai pada tabel distribusi $5 \%$ sebesar 1,988 , maka thitung $(-2,425)>t_{\text {tabel }}$ $(-1,988)$. Hal ini berarti variabel kehandalan mempunyai pengaruh yang signifikan. Hal ini juga diperkuat dengan nilai signifikan $0,05 \quad(0,017>0,05)$ artinya variabel kehandalan berpengaruh signifikan terhadap loyalitas pasien untuk berkunjung dan berobat pada RS. Kusta Dr. Rivai Abdullah Provinsi Sumatera Selatan.

3. Daya Tanggap Terhadap loyalitas Pasien Menurut hasil perhitungan statistic ternyata bahwa faktor daya tanggap mempunyai hubungan positif, hal ini berarti bila faktor daya tanggap meningkat maka loyalitas pasien untuk berkunjung dan berobat 
pada RS. Kusta Dr. Rivai Abdullah Provinsi Sumatera Selatan juga meningkat pula. Hal ini terbukti dengan nilai thitung untuk variabel ini sebesar 1,999. Sementara itu nilai pada tabel distribusi $5 \%$ sebesar 1,988, maka thitung $(1,999)>t_{\text {tabel }}$ $(1,988)$. Hal ini berarti variabel daya tanggap mempunyai pengaruh yang signifikan. Hal ini juga diperkuat dengan nilai signifikan $0,05 \quad(0,049<0,05)$ artinya variabel daya tanggap berpengaruh signifikan terhadap loyalitas pasien untuk berkunjung dan berobat pada RS. Kusta Dr. Rivai Abdullah Provinsi Sumatera Selatan.

4. Jaminan Terhadap loyalitas Pasien

Menurut hasil perhitungan statistik ternyata bahwa faktor jaminan mempunyai hubungan positif, hal ini berarti bila faktor jaminan meningkat maka loyalitas pasien untuk berkunjung dan berobat pada RS. Kusta Dr. Rivai Abdullah Provinsi Sumatera Selatan juga meningkat pula. Hal ini terbukti dengan nilai $t_{\text {hitung }}$ untuk variabel ini sebesar 2,425. Sementara itu nilai pada tabel distribusi $5 \%$ sebesar 1,988, maka thitung $(2,425)>$ tabel $(1,988)$. Hal ini berarti variabel jaminan mempunyai pengaruh yang signifikan. Hal ini juga diperkuat dengan nilai signifikan 0,05 $(0,017>0,05)$ artinya variabel jaminan berpengaruh signifikan terhadap loyalitas pasien untuk berkunjung dan berobat pada RS.Kusta Dr. Rivai Abdullah Provinsi Sumatera Selatan.

5. Kemudahan Terhadap Loyalitas Pasien menurut hasil perhitungan statistik ternyata bahwa faktor kemudahan mempunyai hubungan positif, hal ini berarti bila faktor jaminan meningkat maka loyalitas pasien untuk berkunjung dan berobat pada RS. Kusta Dr. Rivai Abdullah Provinsi Sumatera Selatan

\section{J. KESIMPULAN DAN SARAN}

1) Kesimpulan

a) Hasil pengujian menunjukkan bahwa variabel bukti langsung, kehandalan, daya tanggap, jaminan dan kemudahan secara simultan berpengaruh signifikan terhadap loyalitas pasien di RS. Kusta Dr. Rivai Abdullah Provinsi Sumatera Selatan. Hasil pengujian uji $\mathrm{F}$ secara simultan dihasilkan bahwa variabel bukti langsung, kehandalan, daya tanggap, jaminan dan kemudahan secara simultan (bersama-sama) mempengaruhi cukup kuat terhadap loyalitas pasien. Hal ini terbukti dengan $F_{\text {hitung }}$ lebih besar yaitu 12,988 dibandingkan dengan $F_{\text {tabel }}$ sebesar 2,478

b) Berdasarkan hasil analisis regresi secara parsial dapat diketahui hasil perhitungan adalah bahwa variabel bukti langsung, daya taggap, jaminan dan kemudahan berpengaruh signifikan, sedangkan variabel kehandalan tidak berpengaruh atau tidak signifikan dapat ditunjukkan dengan nilai thitung sebesar 1,053 lebih kecil dari pada nilai tabel 1,988 dan angka signifikan lebih besar 0,05

c) Dari nilai koefisien regresi dapat diketahui bahwa diantara kelima variabel bebas yaitu bukti langsung, kehandalan, daya tanggap, jaminan dan kemudahan yang dominan mempengaruhi loyalitas pasien di 
RS. Kusta Dr. Rivai Abdullah Provinsi diuraikan sebelumnya, maka peneliti memberikan saransaran sebagai berikut:

1) Dari hasil uji t (parsial) diketahui bahwa variabel bukti langsung, daya tanggap, jaminan dan kemudahan memiliki pengaruh yang lemah terhadap loyalitas pasien, maka pihak pimpinan RS. Kusta Dr. Rivai Abdullah Provinsi Sumatera Selatan sebaiknya mempertimbangkan dan memperhatikan kebijakan yang berhubungan dengan loyalitas pasien dari sudut pandang yang lebih luas.

2) Ditengah-tengah persaingan rumah sakit sekarang ini maka hendaknya Pimpinan RS. Kusta Dr. Rivai Abdullah Provinsi Sumatera Selatan mempertahankan sekaligus meningkatkan kualitas baik pegawai dan para medis, saran dan prasarana dan lainlainnya yang telah ada. Karena dengan cara yang telah ada pasein merasa mendapat kemudahan dalam pelayanan untuk berobat dan berkunjung di RS. Kusta Dr. Rivai Abdullah Provinsi Sumatera Selatan. Pimpinan, para medis dan karyawan rumah sakit hendaknya cepat tanggap dalam merespon keinginan dan kebutuhan pasien yang akan berobat dan berkunjung di RS. Kusta Dr. Rivai Abdullah Provinsi Sumatera Selatan.

\section{2) Saran}

Sumatera Selatan adalah variabel kemudahan. Jadi hipotesis akan variabel bebas yang dominan mempengaruhi loyalitas pasien untuk berobat dan berkunjung di RS. Kusta
Dr. Rivai Abdullah Provinsi Sumatera Selatan tidak terbukti.

Berdasarkan kesimpulan yang telah juga meningkat pula. Hal ini terbukti dengan nilai thitung untuk variabel ini sebesar 4,214. Sementara itu nilai pada tabel distribusi 5\% sebesar 1,988, maka thitung $(4,214)>$ $t_{\text {tabel }}(1,988)$. Hal ini berarti variabel kemudahan mempunyai pengaruh yang signifikan. Hal ini juga diperkuat dengan nilai signifikan 0,05 (0,017 > $0,05)$ artinya variabel kemudahan berpengaruh signifikan terhadap loyalitas pasien untuk berkunjung dan berobat pada RS. Kusta Dr. Rivai Abdullah Provinsi Sumatera Selatan.

\section{DAFTAR PUSTAKA}

Griffin, Jill, 2002, Customer Loyality, Penerbit Erlangga, Jakarta.

Ghozali, Imam, 2006. Aplikasi Analisis Multivariat Dengan Program SPSS, Mediakom, Yogyakarta

Edy Sutrisno. 2009. Manajemen Sumber Daya Manusia, Penerbit Prenada Media Group, Jakarta

Jogianto, 2008, Metodologi Penelitian Sistem Informasi, Andi Offset, Yogyakarta

Kotler, Philip, 2009, Manajemen Pemasaran Edisi Milinium, Prehallindo, Jakarta

Laksana, Fajar, 2008, Manajemen Pemasaran, Graha IImu, Yogyakarta

Lupiyoadi, Rambat dan Hamdani, 2006, Manajemen Pemasaran Jasa, Salemba Empat, Jakarta 
Priyatno, Duwi, 2010, Paham Analisis Statistik Data Dengan SPSS, Mediakom, Yogyakarta

Ratih, Hurriyati, 2010. Bauran Pemasaran Dan Loyalitas Konsumen. Alfabeta, Bandung

Riduwan. 2011. Belajar Mudah Penelitian Untuk Guru-Karyawan dan Peneliti Pemula. Bandung : Alfabeta
Santoso, Singgih, 2013, Menguasai SPSS 21 Di Era Informasi, Penerbit PT. Elex Media Komputindo, Jakarta

Siswoyo,. 2007. Metodologi Penelitian Bisnis Teori Dan Aplikasi,UPT, Palembang

Sugiyono, 2010. Statistik Untuk Penelitian.Alfabeta. Bandung. 